Artikel Penelitian

\title{
Hubungan Sanitasi Dengan Status Bakteriologi Koliform dan Keberadaan Salmonella sp pada Jajanan di Sekolah Dasar Wilayah Kecamatan Tembalang, Semarang
}

The Relations with Sanitation and the Status of Bacteriological (Coliform and Existence Salmonella sp) in Region Elementary School in Tembalang, Semarang

Ririh Citra Kumalasari ${ }^{1}$, Martini ${ }^{1}$, Susiana Purwantisari ${ }^{2}$

${ }^{1}$ Bagian Epidemiologi, Fakultas Kesehatan Masyarakat Universitas Diponegoro, Semarang

${ }^{2} J u r u s a n$ Biologi, Fakultas Sain dan Matematika, Universitas Diponegoro, Semarang

*Korespondensi dengan penulis (tinihen65@yahoo.co.id)

Artikel ini dikirim pada tanggal 20 Juni 2016 dan dinyatakan diterima tanggal 29 Desember 2016. Artikel ini juga dipublikasi secara online melalui www.jatp.ift.or.id. Hak cipta dilindungi undang-undang. Dilarang diperbanyak untuk tujuan komersial.

Diproduksi oleh Indonesian Food Technologists ® @2017

\begin{abstract}
Abstrak
Foodborne disease adalah suatu penyakit yang disebabkan oleh adanya mikroorganisme hidup yang masuk bersama makanan. Produk pangan yang tidak memenuhi persyaratan mutu, keamanan dan cemaran bakteri patogen dapat mengakibatkan terjadinya foodborne disease. Anak sekolah merupakan usia yang rentan terhadap infeksi bakteri sehingga membutuhkan makanan yang cukup secara kuantitas dan kualitas agar memiliki keadaan atau status gizi yang baik. Penelitian ini bertujuan untuk mengetahui hubungan sanitasi dengan kontaminasi bakteri pada makanan jajanan di kantin sekolah dasar yang berada Kecamatan Tembalang. Penelitian ini dilakukan berdasarkan analitik observasional dan pendekatan cross sectional. Sampel penelitian sejumlah 48 jajanan yang dijual di sekolah dasar. Pemeriksaan kontaminasi bakteri didasarkan angka koliform dan Salmonella sp. Data dianalisis dengan Chi-squre test. Hasil penelitian menunjukkan jajanan yang dijajakan di kantin Sekolah Dasar yang tidak memenuhi syarat kesehatan sebesar $85 \%$ karena mengandung koliform, dan sebanyak $40 \%$ telah terkontaminasi Salmonella. Disimpulkan bahwa faktor sanitasi dan hygiene penjual berhubungan dengan kontaminasi bakteri pada makanan jajanan. Pendidikan kesehatan tentang pengelolaan makanan yang aman bagi anak sekolah perlu diberikan pada penjual makanan di sekolah dasar.
\end{abstract}

Kata kunci: bakteri, jajanan, koliform, salmonella

\begin{abstract}
Foodborne disease is a disease caused by pathogenic microorganisms that enter with food. Food products that do not meet the requirements of quality, safety and contamination of pathogenic bacteria may result in foodborne disease. School-age child is susceptible to bacterial infections and need sufficient food in quantity and quality so as to have a state or a good nutritional and can strengthen the body's immune system. This study aims to determine the relationship between sanitation and bacterial contamination of street food in the school cafeteria in Tembalang. Semarang. This research used observational analytic and cross sectional approach. The research used 48 sample of snacks that were sold in elementary schools. Examination was done to calculate coliform bacteria and Salmonella sp. Data were analyzed with Chisqure test. The results showed that $85 \%$ of snacks was contaminated by Coliform and $40 \%$ of snack was contaminated with Salmonella. The factors associated with bacterial contamination and bacteriological status in elementary school snacks were knowledge of the seller, the seller sanitation practices, as well as sanitary place to sell. Hygienic education on management to prepare food should be conducted.
\end{abstract}

Keywords: bacteria, snack, coliform, salmonella, foodborne disease

\section{Pendahuluan}

Insidensi foodborne disease di dunia meningkat terus dan terjadi outbreak. Di Indonesia, foodborne disease pada tahun 2014 menduduki peringkat pertama dari 10 besar penyakit rawat inap di rumah sakit. Posisi pertama yaitu penyakit diare dan gastroenteritis karena infeksi tertentu, posisi kedua demam tifoid dan paratifoid menduduki posisi ketiga. Hasil Riset Kesehatan menyatakan, angka prevalensi nasional untuk diare adalah sebesar 3,5\%. Dimana provinsi Jawa Tengah merupakan salah satu provinsi dengan prevalensi diare klinis $>9 \%$ serta menempati urutan ketiga jumlah perkiraan kasus diare yakni sebanyak
1.337.427 jiwa pada tahun 2015 (Kementrian Kesehatan Republik Indonesia, 2012). Jumlah penderita diare di Kota Semarang tahun 2015 sebanyak 42.349 penderita dengan angka kesakitan sebesar 23 per 1000 penduduk. Dari angka tersebut cakupan diare pada golongan umur lebih dari 5 tahun tercatat sebanyak 26.264 penderita. Data dari Dinas Kesehatan Kota Semarang pada tahun 2015 menunjukkan bahwa diantara 17 kecamatan, Kecamatan Tembalang memiliki angka kejadian diare yang masih cukup tinggi yaitu 28-55 per 1000 penduduk (Dinas Kesehatan Kota Semarang, 2013) 
Di Indonesia, demam tifoid merupakan masalah kesehatan masyarakat dengan kejadian antara 350-810 kasus per 100.000 penduduk setiap tahun. Hasil riset kesehatan dasar tahun 2013 menunjukkan bahwa prevalensi demam tifoid sebesar $1,6 \%$. Berdasarkan data dari WHO, Provinsi Jawa Tengah merupakan provinsi dengan demam tifoid yang cukup tinggi yaitu $2,16 \%$. Profil Kesehatan Indonesia tahun 2015 menyatakan demam tifoid atau paratifoid menempati urutan ke 3 dari 10 penyakit terbanyak pasien rawat inap di rumah sakit tahun 2015 yaitu sebanyak 41 (Syahrurachman, 2010). Data dari WHO (2015) dan Kementrian Kesehatan Republik Indonesia (2012) menunjukkan bahwa pada tahun 2015 kasus demam tifoid di wilayah Kecamatan Tembalang sebanyak 788 kasus dengan kasus pada usia sekolah dasar (5-12 tahun) sebesar 298 kasus. Menurut penelitian yang dilakukan oleh Dyah Puji pada tahun 2015 di jajanan sekitar SD di wilayah Semarang, kontaminasi E. coli positif pada makanan $61,3 \%$, pada minuman sebesar $52 \%$ sedangkan kualitas air bersih $68 \%$ yang tidak memenuhi syarat. (Hidayat, 1995). Pada penelitian yang dilakukan Endah Setyorini pada jajanan kantin SD di wilayah Gunung Pati Kabupaten Semarang, yang memiliki MPN melebihi batas yang ditentukan sekitar $69,2 \%$ (Direktorat Jendral Pembinaan Kesehatan Masyarakat, 2004)

Bakteri sangat erat kaitannya dengan kondisi kebersihan, bahkan adanya bakteri indikator sanitasi (Fardiaz, 2000) Salah satu bakteri yang sering dijadikan indikator terjadinya pencemaran makanan adalah Koliform. Bakteri-bakteri indikator sanitasi umumnya adalah bakteri yang lazim hidup pada usus manusia. Salmonella merupakan bakteri indikator keamanan pangan. Hal ini karena semua serotipe Salmonella yang diketahui di dunia ini bersifat patogen. Anak di bangku Sekolah Dasar termasuk kelompok umur yang rentan terhadap kejadian penyakit, maka perlu diperhatikannya asupan yang masuk dalam diri anak. Jika kualitas makanan jajanan buruk akan mempengaruhi proses belajar mengajar dan berdampak pada prestasi belajar anak di Sekolah. Selain itu, anak Sekolah Dasar masih dalam masa tumbuh kembang. Berdasarkan hal tersebut, maka perlu dilaksanakannya suatu penelitian untuk mengetahui total kuman Koliform dan keberadaan Salmonella sp pada jajanan di Sekolah Dasar Kecamatan Tembalang, Semarang. Penelitian ini bertujuan untuk Menganalisis status mikrobiologis makanan yang dijual di sarana jajanan Sekolah Dasar di Kecamatan Tembalang

\section{Metode Penelitian}

Penelitian ini merupakan penelitian analitik observasional dengan desain studi cross sectional dengan sampel berupa makanan yang dijual di kantin dan luar kantin salah satu Sekolah Dasar di wilayah
Kecamatan Tembalang. Populasi dari penelitian ini adalah 48 Sekolah Dasar di Wilayah Kecamatan Tembalang dengan pengambilan teknik pengambilan total sampling. Sampel diperoleh dengan cara membeli semua makanan yang dijual di kantin dan di luar kantin berupa gorengan dan cilok dengan wadah sesuai yang digunakan pedagang pada saat menjual makanannya sejumlah 96 sampel makanan. Penelitian dilakukan di Laboratorium Terpadu Fakultas Kesehatan Masyarakat. Metode yang digunakan adalah kultur. Untuk pemeriksaan Salmonella $s p$ digunakan media Selenite Enrichment Broth dan Salmonella Shigella Agar (SSA). Sampel ditanam pada media Selenith Enrichmen Broth lalu diinkubasi selama 24 jam. Hasil perbanyakan ditanam pada media SSA lalu diinkubasi kembali selama 24 jam. Selanjutnya koloni tersangka ditanam ke media biokimia yang terdiri Simmon Citrate, Indol, Motil, dan TSIA lalu diinkubasi 24 jam kemudian dilakukan pembacaan hasil.Selain dengan pengambilan sampel penelitian ini juga mengukur sanitasi penjual makanan yang di golongkan pada pengetahun sanitasi, praktik sanitasi, kualitas makanan, penyimpanan makanan, dan sanitasi tempat. Hasil dari laboratorium dan observasi di analisis secara univariat dan bivariat dengan menghubungkan antara variabel bebas dengan variabel terikat dengan uji chi square.

\section{Hasil dan Pembahasan}

Jumlah Sekolah Dasar di Kecamatan Tembalang sebanyak 48 Sekolah Dasar. Namun terdapat 2 Sekolah yang telah tereliminasi dikarenakan tidak ditemukannya sampel makanan yang dimaksud oleh peneliti yaitu gorengan pada kantin sekolah dan cilok (makanan asal daerah Jawa Barat yang terbuat dari tapioka) pada pedagang kaki lima. Dua SD ini yaitu MI Falahiyah di Kelurahan Rowosari dan MI Iftahul Ulum di Kelurahan Sambiroto. Sedangkan terdapat 2 Sekolah Dasar yang tidak ada sampel gorengan yaitu SD AlAzzam dan Bina Harapan. Didapat jumlah sampel cilok 46 dan sampel gorengan 44, maka jumlah sampel keseluruhan sebanyak 90. Gambaran status bakteriologi yang diukur dari standar Koliform dengan metode MPN dan menggunakan tabel Mac Crady serta melihat keberadaan Salmonella sp.

Sebagian besar sampel makanan yang diambil dari kantin dan PKL di lingkungan sekolah tidak memenuhi syarat MPN Koliform (67,8\%), dalam Tabel 1. Cilok lebih besar MPN yang tidak memenuhi syarat jika dibanding dengan jajanan kantin (70,0\%). Besar sampel yang terkontaminasi Salmonella sebanyak $37,8 \%$ dan kemudian diidentifikasi spesies Salmonella yang ditemukan 4 jenis Salmonella yang ditemukan (Tabel 3). Oleh karena itu didapatkan status bakteriologi pada jajanan disekitar sekolah dasar. Sebagian sampel makanan terkontaminasi bakteri yaitu Koliform dengan MPN tidak memenuhi syarat dan ditemukannya Salmonella sebesar $82,2 \%$. 
Tabel 1 Kontaminasi Bakteri pada Makanan Jajanan Anak Sekolah Dasar

\begin{tabular}{|c|c|c|c|c|c|c|c|c|}
\hline \multirow[t]{4}{*}{ Jenis Makanan } & \multicolumn{8}{|c|}{ Parameter } \\
\hline & \multicolumn{4}{|c|}{ Koliform } & \multicolumn{4}{|c|}{ Salmonella $s p$} \\
\hline & \multicolumn{2}{|c|}{ TMS } & \multicolumn{2}{|c|}{ MS } & \multicolumn{2}{|c|}{ Ditemukan } & \multicolumn{2}{|c|}{ Tidak } \\
\hline & $f$ & $\%$ & $f$ & $\%$ & $f$ & $\%$ & $f$ & $\%$ \\
\hline Gorengan Kantin & 29 & 66,0 & 15 & 34,0 & 15 & 34,0 & 29 & 66,0 \\
\hline Cilok & 32 & 70,0 & 14 & 30,0 & 19 & 41,3 & 27 & 58,7 \\
\hline Total & 61 & 67,8 & 29 & 32,2 & 34 & 37,8 & 56 & 62,2 \\
\hline
\end{tabular}

Keterangan : TMS = Tidak Memenuhi Syarat Kesehatan, MS = Memenuhi Syarat Kesehatan

Tabel 2. Status Kontaminasi Bakteri Berdasarkan Parameter koliform dan Salmonella pada Makanan Jajanan Anak Sekolah Dasar

\begin{tabular}{lcccc}
\hline Jenis Makanan & \multicolumn{4}{c}{ Status Bakteriologi Jajanan } \\
\cline { 2 - 5 } & \multicolumn{3}{c}{ Tidak Memenuhi Syarat (TMS) } & \multicolumn{2}{c}{ Memenuhi Syarat (MS) } \\
\cline { 2 - 5 } Gorengan & $\mathrm{f}$ & $\%$ & $\mathrm{f}$ & $\%$ \\
Cilok & 37 & 84,1 & 7 & 15,9 \\
Total & 37 & 80,0 & 9 & 20,0 \\
& 74 & 82,2 & 16 & 17,8 \\
\hline
\end{tabular}

Terdapat 4 jenis Salmonella yang ditemukan dan spesies Salmonella yang banyak ditemukan pada sampel adalah jenis Salmonella choleraesius sebanyak $50 \%$. Sedangkan Salmonella parathypi A dan B yang menyebabkan demam tifoid juga banyak ditemukan. Adapula jenis Salmonella yang masih jarang yaitu Salmonella gallinarum pada 1 sampel makanan $(3,0 \%)$

Pengetahuan Penjual gorengan di kantin dan cilok di lingkungan sekolah dengan diberikan 10 pertanyaan dengan masing-masing point memiliki skor 10, maka hasil dari pengetahuan penjual gorengan di kantin sekolah. Penjual jajanan di sekolah sebagian besar memiliki pengetahuan yang kurang baik mengenai sanitasi makanan sebanyak 58 orang $(64,5$ $\%)$, seperti dalam Tabel 4. Item pertanyaan dalam penentuan pengetahuan terdiri dari sanitasi, makanan sehat, mencuci tangan, kebersihan diri, dan sanitasi tempat. Menurut Notoatmodjo, pendidikan dan pengetahuan yang cukup tinggi dapat berguna untuk membina proses intelektual penjamah makanan, dan pengetahuan responden tersebut diharapkan dapat meningkatkan kesadaran terhadap sanitasi perorangan. Semakin besar pengetahuan yang dimiliki seseorang, maka semakin besar keinginannya untuk dapat memanfaatkan pengetahuan dan ketrampilan (Supardi, 2009)

Tabel 3 Jenis spesies Salmonella yang teridentifikasi pada Makanan Jajanan Anak Sekolah Dasar

\begin{tabular}{llcc} 
No & Jenis Salmonella & Frekuensi & $\begin{array}{c}\text { Persentase } \\
(\%)\end{array}$ \\
\hline 1. & Salmonella choleraesius & 17 & 50,0 \\
2. & Salmonella parathypi $A$ & 8 & 23,5 \\
3. & Salmonella parathypi $B$ & 8 & 23,5 \\
4. & Salmonella gallinarum & 1 & 3,0 \\
\hline
\end{tabular}

Sebagian besar penjual belum mengetahui bagaimana tindakan penanganan makanan, belum mengetahui penggunaan alat pelindung dan alat bantu capitan ketika menjamah makanan, dan belum mengetahui bagaimana seharusnya cara penyimpanan makanan yang telah matang. Hasil uji statistik hubungan antara pengetahuan penjual makanan dengan status bakteriologi diperoleh nilai $p$ yaitu 0,035 $(p<0,05)$, ada hubungan yang bermakna antara pengetahuan penjual dengan status bakteriologi pada gorengan di kantin Sekolah Dasar di Kecamatan Tembalang.

Dalam penentuan praktik sanitasi, peneliti melakukan observasi penggunaan alat-alat serta menanyakan kepada responden terkait kebiasaan yang dilakukan dalam menerapkan sanitasi makanan di sekolah dasar tersebut. Praktik sanitasi dikatakan baik apabila penjual telah menerapkan lebih dari $50 \%$ parameter (Tabel 4) yang telah ditentukan, maka hasil dari observasi dan kuesioner terkait praktik sanitasi. Penjual gorengan di kantin Sekolah dan cilok di lingkungan sekolah sebagian besar belum menerapkan praktik sanitasi sebesar 60 orang $(54,5 \%)$ dalam menentukan praktik sanitasi terdiri dari beberapa hal diantaranya penggunaan celemek, penggunaan tutup kepala, mencuci tangan, kondisi lap, dan kebersihan diri. Penjamah makanan jajanan adalah orang yang langsung maupun tidak langsung berhubungan dengan makanan dan peralatannya sejak persiapan hingga penyajian, penjual gorengan merupakan penjamah utama gorengan (Notoatmodjo, 2010)

Tabel 4 Gambaran Pengetahuan, Praktik dari responden penelitian dan Kualitas Makanan jajanan Anak Sekolah Dasar Item Pernyataan Frekuensi Persentase $(\%)$

\begin{tabular}{lll}
\hline Pengetahuan & 58 & 64,5 \\
Kurang baik & 32 & 35,5 \\
Baik & & \\
Praktik Sanitasi & 60 & 66,7 \\
Tidak Menerapkan & 30 & 33,3 \\
$\begin{array}{l}\text { Menerapkan } \\
\text { Kualitas Makanan }\end{array}$ & & \\
$\begin{array}{l}\text { Tidak Baik } \\
\text { Baik }\end{array}$ & 35 & 38,8 \\
Sanitasi Tempat & 55 & 61,2 \\
Tidak Sesuai & & \\
Sesuai & 56 & 64,0 \\
\end{tabular}

Berdasarkan observasi yang dilakukan pada penjual gorengan di kantin Sekolah Dasar di Kecamatan Tembalang, beberapa check list praktik 
sanitasi diamati. Beberapa praktik sanitasi yang berhubungan dengan kontaminasi bakteri dengan nilai $\mathrm{p}<0,05$ adalah penggunaan celemek, mencuci tangan sebelum menangani makanan, dan kondisi lap. Sedangkan untuk penggunaan penutup kepala dan kebersihan kuku tidak berhubungan dengan kontaminasi bakteri. Pada hasil Penelitian Rahmawati (2011) menyatakan bahwa penggunaan celemek dengan kontaminasi bakteri dengan $p=0,039$ (Rahmawati, 2011). Penelitian oleh Susanna dan Hartono (2003) di wilayah Jakarta mencatat 43\% pedagang makanan tidak melakukan cuci tangan baik sebelum dan setelah menjamah makanan. Kebiasaan tersebut dapat menjadi sumber kontaminan terhadap kebersihan makanan yang ditanganinya.

Dalam penentuan kualitas bahan makanan, peneliti melakukan menanyakan kepada responden terkait kualitas bahan makanan. Kualitas makanan dikategorikan baik apabila memenuhi lebih dari $50 \%$ parameter yang telah ditentukan. Sebagian besar jajanan di lingkungan sekolah memiliki kualitas makanan yang baik sebesar 55 orang $(61,2 \%)$. Hal ini didasarkan pada kualitas bahan makanan, kualitas pengolahan, dan kualitas penyimpanan. Dan yang merupakan faktor yang berhubungan dengan kualitas penyimpanan makanan. Hasil analisis bivariat oleh Rahmawati (2011) menunjukkan ada perbedaan yang signifikan antara penyimpanan makanan dengan kontaminasi bakteri pada jajanan $(p=0,015)$ di kantin Sekolah Dasar Kecamatan Banyumanik (Rahmawati, 2011). Namun berbeda dengan penelitian Uly (2007) yang menyebutkan ada hubungan antara penyimpanan makanan dengan keberadaan bakteri Salmonella dengan nilai $p=0,03$ (Ray, 2001)

Dalam penentuan sanitasi tempat, peneliti melakukan observasi lingkungan sekitar kantin dan peralatan sanitasi penunjang. Sanitasi tempat dikategorikan baik apabila memenuhi lebih dari $50 \%$ parameter yang telah ditentukan, maka hasil dari observasi terkait sanitasi tempat penjual gorengan di kantin sekolah sebagian besar memiliki sanitasi tempat berjualan yang tidak sesuai sebesar 28 orang (64,0\%). Dalam penentuan sanitasi tempat terdiri dari jarak sumber pencemar, kondisi tempat sampah, dan keberadaan vektor. Jarak sumber pencemar berhubungan dengan kontaminasi bakteri. Sesuai dengan penelitian terdahulu yang menyebutkan bahwa jarak sumber pencemar mempengaruhi kontaminasi kuman pada jajanan di kanti SD dengan nilai $p=0,023$ (Hidayat, et al.,1995).

\section{Kesimpulan}

Sampel makanan yang memiliki angka Most Probable Number Koliform tidak memenuhi syarat sebanyak $67,8 \%$ dan kontaminasi bakteri Salmonella sp pada jajanan di Sekolah Dasar Kecamatan Tembalang $37,8 \%$ sehingga status bakteriologi makanan jajanan di Sekolah Dasar yang terkontaminasi sebanyak 82,2 \%. Dalam penelitian mikrobiologi penanaman bakteri Salmonella ditemukan 4 jenis
Salmonella pada jajanan kontaminan, yaitu Salmonella choleraesius, Salmonella parathypi A, Salmonella parathypi B, dan Salmonella gallinarum. Penelitian ini dapat membuktikan adanya hubungan bermakna antara pengetahuan sanitasi, penggunaan celemek, kegiatan mencuci tangan sebelum menangani makanan, kualitas penyimpanan makanan, dan jarak sumber pencemar dengan status bakteriologi gorengan di kantin Sekolah Dasar Kecamatan Tembalang

\section{Daftar Pustaka}

Kementrian Kesehatan Republik Indonesia. 2012. Profil Data Kesehatan Indonesia. Jakarta.

Dinas Kesehatan Kota Semarang. 2013. Profil Data Kesehatan Kota Semarang. Semarang.

Syahrurachman, A. 2010. Buku Ajar Mikrobiologi Kedokteran: Jakarta. Bina Rupa Aksara.

Hidayat, T.S., Mujianto, T.T., Susanto, D. 1995. Pola Kebiasaan Jajan Murid Sekolah Dasar dan Ketersediaan Makanan Jajanan Tradisional di Lingkungan Sekolah di Provinsi Jawa Tengah dan D. I. Yogyakarta. Widyakarya Nasional Khasiat Makanan Tradisional. Jakarta: Kantor Menteri Negara Urusan Pangan Republik Indonesia.

Direktorat Jendral Pembinaan Kesehatan Masyarakat. 2004. Pedoman pengelolaan dan penyehatan makanan warung sekolah. Direktorat Bina Gizi Masyarakat Depkes RI. Jakarta.

Fardiaz, S. 2000. Riset Mikrobiologi Pangan untuk Peningkatan Keamanan Pangan di Industri. Yayasan Srikandi. Bogor.

Supardi, Sukamto. 2009. Mikrobiologi dalam Pengolahan dan Keamanan Pangan. Bandung Penerbit Alumni.

Notoatmodjo, S. 2010. Metodologi Penelitian Kesehatan. Rhineka Cipta. Jakarta.

Rahmawati P.A. 2011. Faktor Penyebab Kontaminasi Bakteri pada Jajanan di Sekolah Dasar Kecamatan Banyumanik. Skripsi FKM UNDIP. Semarang..

Rosania. 2015. Pengaruh Higiene dan Sanitasi dengan Kontaminasi Salmonella pada Jajanan Sekolah Dasar Kecamatan Mejobo, Kudus. Skripsi tidak diterbitkan. Semarang : S1 IImu Kesehatan Masyarakat UNNES.

Susanna, D., Hartono, B. 2003. Pemantauan Kualitas Makanan Ketoprak dan Gado-gado di Lingkungan Kampus UI Depok Melalui Pemeriksaan Bakteriologis. Makara Seri Kesehatan 7(1): 21-29.

Uly D. 2007. Survey Keberadaan Salmonella sp Dalam Nasi Rames pada Kantin Sekolah Dasar Wilayah Kerja Puskesmas Sambiroto. Skripsi S1 FKM Universitas Diponegoro.

Ray B. 2001. Fundamental Food Microbiology.Boca Raton: CRC Press.

World Health Organization. 2005 Penyakit Bawaan Makanan Fokus Pendidikan Kesehatan. Jakarta: EGC. 2005. 